\title{
The Development of Native Languages in Educational Institutions in the Conditions of the Dispersed Indigenous Small-Numbered Peoples in the North, Siberia and the Russian Far East, in the Republic of Sakha (Yakutia) (on the Example of the Even language)
}

\author{
Uiandina P. Tarabukina* \\ Scientific Research Institute of National Schools \\ in the Republic of Sakha (Yakutia) \\ 22 October Str., Yakutsk, \\ The Republic of Sakha (Yakutia), 677027, Russia
}

Received 03.02.2015, received in revised form 21.04.2015, accepted 17.05.2015

The paper describes the system of preservation, study and development of the official languages of the indigenous small-numbered peoples of the North in the educational organizations of the republic of Saha (Yakutiya) on the example of the Even (Lamut) language. The author states the role of nomadic schools in order to guarantee an access to general education for the children of reindeer herders, fishermen, hunters, who experience the nomadicic lifestyle with their parents. The author observes the provision of educational organizations and nomadic schools with textbooks and study guides.

Keywords: educational organizations, Even (Lamut) language, nomadic school, indigenous smallnumbered peoples of the North, system of the development of native language, normative-regulative legislation, textbooks and study guides, dispersed population of indigenous small-numbered peoples of the North.

Research area: pedagogy, culture studies.

The Republic of Sakha (Yakutia) is a multinational republic, and the indigenous smallnumbered peoples of the North live in places of compact and dispersed residence in different uluses (settlement areas). Settling as a dispersed population over a large area of the northern and arctic areas of the Republic of Sakha, the indigenous small-numbered peoples of the North, including the Evens, have had a kind of nomadic and semi-nomadic lifestyle for centuries, so their livelihoods are inextricably connected with the traditional lands and customs.

Preservation and development of the native languages of the indigenous small-numbered peoples of the North, Siberia and the Russian Far East is one of the urgent problems of the implementation of the language and national policies. Meanwhile, the native languages of the indigenous small-numbered peoples of the North,

(C) Siberian Federal University. All rights reserved

* Corresponding author E-mail address: yandina-49@mail.ru 
Siberia and the Far East are in a very difficult situation.

The problem is in the focus of normative and legal acts regulating the issues of language of the indigenous small-numbered peoples in the Russian Federation and the Republic of Sakha (Yakutia), the researchers have conducted monitoring research in educational institutions in order to identify the functioning of the languages of the indigenous small-numbered peoples of the Republic of Sakha (Yakutia), also there has been made an analysis of educational and methodical books concerning Even language.

The study of native languages, protection and preservation of cultural and linguistic diversity of the indigenous small-numbered peoples is one of the priorities of the state policy of the Republic of Sakha (Yakutia).

The Republic of Sakha (Yakutia) on the basis of laws and legislation of the Russian Federation has adopted a lot of legal acts, regulations, decrees, resolutions, which provide opportunities for the preservation, study and development of the official languages of the indigenous smallnumbered peoples (the Evens, the Evenks, the Yukaghir Peoples, the Chukchi and the Dolgans) on a par with the Russian language as a state one and the Yakut language.

Currently, 22 uluses (settlement areas) of the country, including the city of Yakutsk, have 38 secondary schools, teaching the native language of the indigenous small-numbered peoples of the North, including 22 schools with the Even ethno-cultural component. The 20 pre-school educational institutions, located in 14 regions of the Republic of Sakha (Yakutia), teach the language and culture of the indigenous smallnumbered peoples.

In the Republic of Sakha (Yakutia) there are 14educational institutions where several native languages of the indigenous small-numbered peoples of the North and the Sakha language are taught.

In order to ensure access to education for the children of reindeer herders, fishermen, hunters, with their parents leading a nomadic lifestyle; in order to create conditions for the families to live together, 11 districts in traditional lands of the indigenous small-numbered peoples created 11 nomadic educational institutions, with an enrollment of 111 students. They include 6 Even nomadic schools. During summer the summer nomadic camps function in reindeer herders' community bases.

In 2006 the project "Nomadic school promotes literacy among students belonging to the indigenous peoples, by strengthening the capacity of community education among the nomadic peoples of the North of the Republic of Sakha (Yakutia)" was developed in the framework of the "Education for All" project with the assistance of UNESCO in Moscow.

Nomadic school is an independent legal educational organization or a branch of an educational organization in areas where the indigenous small-numbered peoples of the North live.

Regulatory support of nomadic educational organizations include the following documents: Concept of nomadic educational institutions of the Republic of Sakha (Yakutia) № 228, dated April 22, 2005; Law of the Republic of Sakha (Yakutia) "On nomadic schools in the Republic of Sakha (Yakutia)" of 22.07.2008, 3 N 74-IV; Law of the Republic of Sakha (Yakutia) "On the norms of financing the government cost of providing the citizens with the rights to receive general and free preschool, primary, comprehensive, basic, secondary (full) education, as well as additional education in educational institutions" of 18.06.2009, 3 N 322-IV; Law of the Republic of Sakha (Yakutia) "On state support of rural educational institutions”, 3, № 169-II; Law of 
the Republic of Sakha (Yakutia) of 27.11.2014 1372-3 N 295-V "On amendments to the Law of the Republic of Sakha (Yakutia) "On nomadic schools in the Republic of Sakha (Yakutia)" ("Il Tumen", N 50, 19.12.2014).

The structure of the educational process also includes family education and self-education; respectively, the list of categories of nomadic schools is extended due to family nomadic schools (group) - a branch of the educational organization (supportive school, pre-school organization). These schools implement the program of preschool, primary general, basic general, secondary education; and children are taught by the members of the family (clan) communities of the indigenous small-numbered peoples in the North in the places of their traditional land management and usual economic activities. External studies are excluded from educational programs; the list of forms of implementation of educational programs, that are established by founders of nomadic schools on the basis of agreement between the educational institutions and pupils' parents and reflected in the Charter of the nomadic schools, includes full-time, part-time and correspondence forms of education. The new version contains an article concerning the funding of nomadic schools.

Basic models of nomadic educational organizations are the following: nomadic school - kindergarten, community school, tutor school, taiga school, nomadic school - ethnocultural center, network nomadic school, summer nomadic school and family nomadic school.

Flexible planning of educational process has been legalized taking into account the production cycle in reindeer herding; nomadic schools in areas of winter reindeer bases are regarded as small staffing schools and included in a special list of small schools, which is approved by decision of the Government of the Republic and financed at actual cost. The system of remuneration of teachers in nomadic schools implies the possibility of an individual approach to their remuneration. As for financing the independent legal nomadic schools the salary is calculated taking into account the number of teachers. The structural divisions are funded regarding industry wage system, basic school schools are funded per capita. When calculating the amount of funding exceeds by 3 times the number of nomadic people. Funding comes from the Ministry of Education of the Republic of Sakha (Yakutia).

Educational organizations have an adequate number of staff. Teachers for educational institutions are prepared by Northern Branch of the Institute of Languages and Cultures of the Peoples of the North-East of the Russian Federation, tutors for nomadic schools are taught at the Pedagogical Institute NEFU named after M.A. Kirov.

According to the law "On nomadic schools" summer camps have received the status of nomadic schools and are now funded as schools.

Centre for Development of Nomadic Educational Institutions has developed and implemented the Program "Socialization of children, leading a nomadic way of life with their parents" as a component of the project for the development of the nomadic educational organizations in the framework of UNESCO's "Education for All". The complex of measures for socialization of children of nomadic schools is realised on the following levels: 1) zonal (during the national holidays, such as "Day of Reindeer Herder", "Bakaldyn", "Evinek" and others); 2) republican (the organization of leisure in the Republic of Sakha (Yakutia); 3) federal (all-Russian Children's Centers "Ocean”, "Orlyonok"); 4) international (online conferences, international centers, etc.).

The nomadic education system provides upbringing of the patriots of the North, who will be capable of activity in terms of civil society and market economy. Graduates of nomadic 
schools enter colleges and universities. Some of them, having got the education, return to their native nomadic schools as teachers, specialists in reindeer, or to head the community.

At the present stage of development of material-technical base of nomadic schools, general secondary education and their methodical support the issue of financing educational practices is one of the most urgent problems.

Due to researchers' team the Even schools are now in more favourable position compared with other peoples of the North.

Currently, the Even schools, including nomadic schools, have the program on the Even language and literature, textbooks, literature up to $11^{\text {th }}$ grade. The authors of textbooks, study guides, dictionaries are: V.A. Robbek, Kh.I. Dudkin, N.I. Gladkova, O.N. Keimetinova, T.K. Kopyrina, A.D. Keimetinova, V.S. Keimetinov-Bargachan, U.P. Tarabukina, A.A. Keimetinova, A.V.Krivoshapkin, R.S. Nikitina, Ie.K. Tarabukina, A.A. Burykin, Ie.Ie. Beglova, A.D. Sleptsova, Ie.N. Bokova, V.A. Keimetinov et al.

Thanks to the implementation of the Concept of modernization and development of the national school, in 1992 there was introduced the subject "Culture of the Indigenous Peoples of Yakutia". The purpose of the subject is to study local history, culture and traditions of the Yakut people, the culture of the indigenous smallnumbered peoples of the Republic's North.

A.V. Krivoshapkin, R.S. Nikitina made a study guide "Khotugu noruottar kulturalara" (Culture of the Peoples of the North) for grades $5-6,7-8,9-11$. The book in a simple form tells the history of the culture, customs and traditions of the indigenous small-numbered peoples of the North, their contemporary culture and oral tradition, about the life and work of prominent figure of the indigenous peoples.

V.S. Keimetinov-Bargachan together with his wife, A.D. Keymetinova, published textbooks and study guides for literary reading "Танаnmaidu book" (Тананмайду книга) in the Even language for grades 5-6, 7-8, 9, as well as an anthology of the Even literature for grade 9.

The textbook "Танаnmaydu book" for grades 10-11 was comprised by a group of authors: A.V. Krivoshapkin, V.S. Keimetinov-Bargachan, et al.

Ie.N. Bokova is the author of the textbook "Evedy folklore" (Эвэды фольклор) of the Evens' folklore for grades 5-9, which became a handbook for each teacher of the Even schools. In the study guide "School theme dictionary of the Even adjectives" (862 adjectives of the Even language) Evdokia Nikolaevna codified adjectives, denoting signs of different meanings. She is also the author of the textbook "The Evens' Clothes".

In connection with the expansion of the role of nomadic tribal communities there is a problem of developing new programs, educational and methodological materials for schools on the uluses' bases. Rozalia Serafimovna Nikitina one of the first undertook the development of the education plan and pilot program for the schools of a new type - nomadic schools. R.S. Nikitina, honored teacher of Russia, recipient of the Excellence in Education Award of the RSFSR, the Master Teacher, Candidate of Pedagogical Sciences, Senior Researcher in Scientific Research Institute of National Schools in the Republic of Sakha (Yakutia), works on the problem of getting students-northerners to know their national roots, national traditions and customs. To introduce the young people to the material and spiritual culture of the native people, she prepared and published a large illustrated textbook "Lessons of ancestors" and the guidelines to this book, directed to the Evens students in grades 1-4. She developed state standard for the indigenous small-numbered peoples' cultures of the North in the Republic of Sakha (Yakutia). The pupil's book, written 
with the teacher A.P. Stepanova. "Evedy terem hupkuttep" (Learning the Even language) for those not speaking the Even language is also timely.

The program of teaching and education of children in the spirit of the ancestors for grades 1-4 in schools of the North, called "Lessons of ancestors" (R.S. Nikitina, A.V. Krivoshapkin) was first developed and approved by the Russian Ministry of Education in 1993.

"hopkil biniten" (Lessons of ancestors) (illustrated by G.A. Krivoshapkin) is the first illustrated textbook on traditional culture for primary grades of the Even schools. The guidelines to the textbook "Lessons of ancestors" for the Even primary school have thirty exemplary lessons on the course "Culture" in primary school. The textbook "Taiga alphabet" (Safety Fundamentals for children in the North) was issued for the pupils of the grade 4 of secondary schools. Taiga alphabet is a new educational area for the schools of the North.

R. S. Nikitina in collaboration with Iekaterina Konstantinovna Tarabukina compiled a textbook "Bug tereнdur induced hupkuchek" (Буг төрэндур инду хупкучэк meaning "Learning to Live on the Earth") in the Even and Russian languages with the workbook on traditional land management and ecology for students of the grades 3-4.

G.M. Fedorov, R.S. Nikitina are the authors of the textbook "The surrounding world" for grade 1 of nomadic schools, which has been translated into the Even language as "Bugu" (trans. Z.A. Stepanova), into the Evenki language as "Buga" (trans. A. Myreeva) and the Russian language (trans. S.V. Vasil'eva). The study guide on the surrounding world is permeated with the idea of the triad of "Nature - Man - Society" that integrates natural science and environmental concepts in harmony with the folk wisdom of pedagogics.
The study guide "Learning to live in the North" (authors - R.S. Nikitina, G.M. Fedorov, Ie.I. Vinokourova) is an exemplary program of traditional knowledge of the indigenous peoples of the Republic of Sakha (Yakutia). The study guide was created within the framework of the project "Teacher of the Arctic" for the northern and Arctic schools of the Republic. It is intended for the organization of extracurricular activities.

Textbooks and teaching aids developed at the Laboratory of the Peoples' of the North School "Scientific Research Institute of National Schools of the Republic of Sakha (Yakutia)", such as the guidelines for nurses and teachers "Ауапна dyut Mut" (Айанна мут дют ("Nature is our home" by U.P. Tarabukina)) on the environment and development of speech, contribute to teaching respect for the nature and environment among the Even children of preschool and early school age. The pupil's book is used in the nomadic Even schools as well.

For children of preschool and primary school age there was published the study guide "Dënturdi alphabet” (Дёнтурди азбука ("Even alphabet in verse" by U.P. Tarabukina)). This book helps young readers to learn the Even alphabet in a playful and entertaining way so to develop the Even language and intonation.

The entertaining material, presented in a textbook for students of the grades 1-4 "Mulgachildyvun" (Мулгачилдывун ("Entertaining Even language grammar" by U.P. Tarabukina)), will help to enrich the vocabulary of students via consolidating their knowledge and skills obtained at the lessons of the Even language. The purpose of this study book is the development of speech and mental activity of pupils.

The integrated textbook "N'өt" (Ньөт ("Source")) for grade 1 of the nomadic schools (authors - U.P. Tarabukina, A.S. Sakerdonova) collected the crumbs of what is called the treasury 
of the Even literature. That is why this textbook is so interesting and valuable. The proposed works to be learned are easily reproducible and push the readers to reflect; they are intonationally original, varied in tempo, rhythm, tone, expression; they develop a culture of creative perception of the text, motivate and encourage children to make new discoveries and write their own creative works.

The book "Giavan" for grade 2 (authors U.P. Tarabukina, A.S. Sakerdonova fosters pupils to work with basic means of language, namely words, sentences, the text.

The textbook on literary reading "Kholiga" (authors - U.P. Tarabukina, O.K. Potapova) teaches reading in Even for grade 2 and takes on the modern requirements of education. The purpose of the textbook is to awaken pupils' interest in learning the native language, to create a situation of a surprise in the class. It implements the following functions: gives information, organizes, teaches.

The study guide on the Even language "The Even language in kindergarten" (authors U.P. Tarabukina, A.S. Sakerdonova) is aimed at teachers and parents, leading a nomadic lifestyle. The study guide includes exemplary lesson plans, exemplary minimum glossary for every age group. The suggested system of lessons, educational games, exercises was designed for the consistent, systematic and deliberate practicing the Even language in the development of children's ability to understand the speech of others and master their own speaking skills.

Members of the Laboratory of the Peoples' of the North School "Scientific Research Institute of National Schools of the Republic of Sakha (Yakutia)" are working to create the syllabus of the language, literature and culture of the indigenous small-numbered peoples of the North in accordance with the federal state standard of general education, where learning the native language of the indigenous small-numbered peoples of the North should be aimed at forming metadisciplinary results and universal educational actions, taking into account the specificity of the subject.

Theresearchershavepreparedadraftprogram teaching the native language and literature of the indigenous small-numbered peoples for those who speak and do not speak the native language. The Republic has Basic curriculum for schools of the indigenous small-numbered peoples in the Republic of Sakha (Yakutia), developed by the Ministry of Education of the Republic of Sakha (Yakutia) and "Scientific Research Institute of National Schools of the Republic of Sakha (Yakutia)", where the number of lessons of the native language is 5 hours for primary school and 4 hours for secondary school.

As a result of monitoring the situation of the native language and culture there were developed:

- materials of monitoring study, aimed at identifying the state of teaching the Even and Evenki language in educational institutions located in places of traditional residence and economic activities of the indigenous small-numbered peoples of the North and the Far East of the Russian Federation;

- materials of metasubject the Even and Evenki language Olympiad;

- exam materials for Russian state exam and basic state exam.

Primary school teachers, teachers of native languages, employees of scientific organizations, scientists are constantly developing electronic textbooks for the study of the native language, dictionaries, cartoons in the native language of the ethnic group. The employees of "Scientific Research Institute of National Schools of the Republic of Sakha (Yakutia)" have developed and launched children information-educational portal "E-netschool" (Ethnic school). In the course of 
the project "Children study the North" there was issued a series of books "Children of the North" in the official languages of the Republic of Sakha (Yakutia), including a book to read in the Even language "Bi - нunmir huten bisem” (“Би нунмир һутэн бисэм” by U.P. Tarabukina, O.K. Potapova, A.S. Sakerdonova).

Development of cognitive activity and accumulation of ethnic values are implemented in educational organizations of the indigenous small-numbered peoples of the North by creating a system of academic and extracurricular activities. Various forms of extracurricular and after-school activities, as well as traditional school activities form special ethnic component in school life; they make a significant contribution to the study of native languages and cultures of ethnic groups. For example, in the Republic of Sakha (Yakutia) the Even language and culture are taught in the form of extracurricular activities through the club "honнаchan" ("Һонначан" meaning "Fawn") in the settlement of Chokurdakh in Allaikhovsky ulus, the club "Менеn unapan" (“Мэнэн уньапан" meaning "Golden Thimble") in municipal budgetary educational organization "Sebian-Kiuelskaia Even national general secondary school named after P.A. Lamutskii" in Kobiaiskii ulus, the puppet theater "Neltenke" (“Ньөлтэнкэ" meaning "Sun") in municipal budgetary educational organization "Andriushkinskaia national general secondary school" in Nizhnekolymskii ulus. In these clubs pupils are introduced to the Even national culture, explore folklore genres, memorize verses, get acquainted with the oral folk art; there are also special classes where children learn folk songs, dances, games, arts and crafts of a certain ethnic group).

The Even schools have established a system of traditional school events dedicated to the native language and culture: songs competitions in Even "hanin ikan" (“Һанин икэн” meaning
"Song of the soul"); the national round dance competitions "heede" (“Һээдьэ"); evenings devoted to the Even writers and poets; games of the ancestors; days (or even a month) of the Even schools; decades of native languages; scientific and practical conferences "Lamutskii readings", "Lebedev readings", "Tarabukinskie readings", etc., Internet conferences on language, literature and culture; metaolympiads of creative compositions in the native languages.

In order to develop pupils' creative activity, their spiritual and moral education, educational organizations hold school scientific-practical conference " $\mathrm{Bi}$ - Hunmir bein bisem, Bi - esilbi hirakamнаatan bisem” (“Би - нунмир бэин бисэм, Би - өсилби һиракамнатан бисэм” meaning "I am the representative of the nation, I am the successor"). The educating objective of the conference is to promote mastering scientific ways of knowing the Evens' world, to improve the research techniques. Another educational objective of the conference is to foster a positive learning motivation, interest in research, making conditions for creative work. Students are interested in studying names of place of their native land, the literary language of the Even writers, such as N.S. Tarabukin, founder of the Even literature, P.A. Lamutskii, founder of the Even children's literature, author of the first novel in Even "The Spirit of the Earth", V.D. Lebedev, poet, the first Even scholar, A.V. Krivoshapkin, national writer of the Republic of Sakha (Yakutia), D.V. Krivoshapkin-Nimkalan, translator, and others. In addition, pupils explore folklore, study the Even names of the inhabitants of their villages. At the conference, pupils submit their reports, which reveal a broad panorama of live observation of the traditional culture of the Evens. Students enjoy a creative approach to the topic under study, they collected materials from their grandparents, parents, relatives, experts on language and culture. 
Teachers of the native languages in Even schools organize interesting lessons of the native language and literature, additional, elective and extra-curricular activities, research work in the school museum. Museum pedagogy greatly enhances northern school teachers' opportunities in solving problems related to the historical, cultural and linguistic education. Museum pedagogy is concentrated on improving children's attention to the surrounding reality; it helps to detect the realities of museum value in the surrounding world; it helps to appreciate the genuine things of bygone times, family heirlooms; it develops intelligence; it gives children a new means for understanding the world and the development of their native language.

Educational activities, aimed at preservation and development of the culture, traditions and language of the indigenous small-numbered peoples of the North, are also carried out through children's dance ensembles. Each school has its own ensemble, such as the folklore ensemble "Noнdan" ("Нондан" meaning "Brow") in Abyiskii ulus (settlement area); the folklore ensembles in Eveno-Bytantaiskii national ulus (settlement area) "Aianessa" (meaning "Happiness"), "Tugusil” (meaning "Bullfiches"); the folklore ensemble "Nerget" (meaning "Sprout") in Ust'-Yanskii ulus; the folklore ensemble "Osiktakan" (meaning "Stars") in Allaikhovskii ulus; the folklore ensembles "heku" (meaning "Shine"), "honнachan" (meaning "Fawn") in Momskii ulus; the folklore ensembles "Maranga" (meaning "Rainbow"), "Solinga" (meaning "Dawn") in Tomponskii ulus; the people's ensemble "Merlenke" (meaning "Snowdrops"), the folklore and dance ensemble "hogin" (meaning "Glow"), the dance ensemble "Nirgin" (meaning "Round Dance") in Kobiaiskii ulus; the folklore and dance ensemble "Khoeen" (meaning "Flow") in Srednekolymskii ulus.
The basis of the repertoire of these ensembles is the ordinary life of the Even people, their customs and ancestral chants, dances and games. Each dance is a piece of life of the Evens. These dances reveal the eternal theme of folk art, the tree of life, miraculous birds, the deer in the beautiful and proud guise, which are symbols of the good, well-being, happiness and hope. They captivate with their beauty, wisdom, diversity and simplicity. At folklore lessons children not only learn the Even language, but also want to know more and more about the rites and traditions of their ethnic group, so they start their own search. Children ensembles, reaching great results, find their individual style. They are participants, awardees, winners of many national, all-Russian, international cultural events.

Students of secondary and nomadic organizations also actively participate in the annual celebrations of national holidays, uniting settlement areas. These holidays include "Neltem bakaldan” (“Ньөлтэм бакалдан” meaning "Meeting of the Sun"), "Day of the Reindeer Herder", "Birthday of a Fawn", "Blossoming Tundra"; traditional Even summer holidays "Evinek" (meaning "Feast"), "Sebd'ek" (meaning "Fun"); autumn holiday "Day of the First Snow", and others.

Competitions on national sports include "hurken omolgo" ("Һуркэн омолго" meaning "Nimble Man”), "Өmcheni” (“Өмчэни”, the name of a hero from the Even legends), deer races for children and students, etc.

Pedagogical staff in the Even children's organizations correctly identified methods of work for the preservation and development of the Even language, the formation of traditional knowledge and the exposure to the cultural, spiritual and moral values of the people of the North in the dialogue of cultures.

The program on preschool education by Kh.I. Dutkin (1990) for teachers and parents, 
leading a nomadic lifestyle, involves physical, mental, moral, aesthetic education and development of preschool children according to age and individual characteristics. On the basis of this program certain preschool institutions in some uluses make their own authors' program. For example, in Srednekolymskii, Tomponskii, Eveno-Bytanaiskiii uluses (settlement areas) the national kindergartens work according to their authors' programs, which are:

1. "Upbringing and education of children on the basis of ethnic pedagogy of the Evens" in Berezovskii kindergarten "Enkechen" in Srednekolymskiiulus(authors-M.P.Zarovniaeva, N.A. Nesterova, etc.);

2. "Teaching speaking Even as the native language in kindergarten" in rural settlement Topolinoe in Tomponskii ulus (authors N.P. Petrova, Ie.G. Golikova);

3. "The Even language and folklore in preschool" in rural settlement Batagai-Alyta in Eveno-Bytanaiskii ulus (authors - V.I. Sleptsova, Z.P. Nikulina).

The relevance of these programs is that they contribute to the formation of the necessary level of speech abilities and speaking skills aimed at enhancing emotional and imaginative spheres of reasoning and that they foster interest in the native language in a multilingual context

The Even language education system in preschool includes preservation of ethnic identity under conditions of dispersed residence of the indigenous small-numbered peoples of the North, and the revival of customs and traditions of the ethnic group .

In kindergartens in Arctic uluses, such as "Fawn" in Allaikhovskii ulus, "Tugutchaan" (meaning "Fawn") in the rural settlement Naiba in Bulunskii ulus in the Republic of Sakha (Yakutia), staff works on acquiring the traditional knowledge and exposing children to the cultural, spiritual and moral values of the ethnic group in the dialogue of cultures. Workers of the kindergarten "Fawn" in Allaikhovskii ulus do their educational work in the form of mini-projects. By implementing these projects, they integrate all educational activity and teaching children their native language. For example, the mini-project "The Even melodists and the Yakut poets" generates love for the native land, the people living in Yakutia on the grounds of literary and musical works of Even poets, storytellers, melodists. This project develops emotional responsiveness, the ability to see oneself in the outside world, knowledge of creative music works, verses of the Even poets.

The introduction to the national culture, the study of the native language have become an integral part of the work on the revival and development of the language and culture of Evens. This is true for the kindergarten "Tugutchaan" in the rural settlement Naiba in Bulunskii ulus. This kindergarten was founded in 1971 and is a basic pre-school educational organization for children of the Arctic, who grow in nomadic families. The main objective is the constant search for creative forms and methods of education, aimed at creating an independent personality, child care, protection of children's rights. Nurses offer substantive developmental environment that enables the child to choose any interesting activity corresponding to their interests and needs.

Taking into account all the positive aspects of the preservation and development of the native languages in under conditions of dispersed residence of the indigenous small-numbered peoples of the North, Siberia and Far East of the Russian Federation, in particular in the Republic of Sakha (Yakutia) on the example of the Even language, the researchers came to the following conclusion. The need for the introduction of modern pedagogical technologies in teaching native languages, realization of the federal state educational standards of primary and general education require to bring teaching 
materials concerning the native languages of the indigenous small-numbered peoples of the North to a qualitatively new level. Courseware and study pack for teaching the native languages should be inferior neither in the quality and content of the publication, nor in the variety of components from other subjects, included in the compulsory part of the basic (general) educational program.

It should be noted that for the study of the native languages of the indigenous smallnumbered peoples the exemplary program should take into account the specifics of their implementation.

\title{
References
}

1. Federal Government Standard.

2. Law of the Republic of Sakha (Yakutia) "On nomadic schools in the Republic of Sakha (Yakutia)" of 22.07.2008.

3. Materials of monitoring study "Functioning of the native language in educational institutions of the indigenous small-numbered peoples of the Republic of Sakha (Yakutia).

4. Materials of research report "Analysis of study guides on the Even language".

5. Scientific-methodical journal "Tatkachiruk" during 2006-2014.

\section{Развитие родных языков в образовательных организациях \\ в условиях дисперсного проживания \\ коренных малочисленных народов Севера, Сибири \\ и Дальнего Востока РФ \\ в Республике Саха (Якутия) \\ (на примере эвенского языка)}

\author{
У.П. Тарабукина \\ Научно-исследовательский институт \\ нащиональных школ Республики Саха (Якутия) \\ Россия, 677027, Республика Саха (Якутия), \\ Якутск, ул. Октябрьская, 22
}

\footnotetext{
В статье описывается система сохранения, изучения и развития официальных языков коренных малочисленных народов Севера в образовательных организачиях Республики Саха (Якутия) на примере эвенского языка. Показана роль кочевых школ в обеспечении доступности общего образования для детей оленеводов, рыбаков, охотников, ведущиих с родителями кочевой образ жизни.

Ключевые слова: образовательные организации, эвенский язык, кочевая школа, коренные малочисленные народы Севера, система развития родного языка, нормативно-правовое обеспечение, учебники и учебно-методические пособия, дисперсное проживание коренных малочисленных народов Севера.
}

Научная специальность: 13.00.00 - педагогические науки, 24.00.00 - культурология. 